\title{
Renovation versus New Construction and Building Decision Tool for Educational Facilities
}

\author{
Carrie Pope, ${ }^{1}$ Eric Marks, ${ }^{2}$ Edward Back, ${ }^{2}$ Tim Leopard, ${ }^{3}$ and Thomas Love \\ ${ }^{1}$ Department of Civil, Construction and Environmental Engineering, School of Civil and Environmental Engineering, \\ University of Alabama, H.M. Comer Hall, Tuscaloosa, AL 35401, USA \\ ${ }^{2}$ Department of Civil, Construction and Environmental Engineering, University of Alabama, \\ H.M. Comer Hall, Tuscaloosa, AL 35401, USA \\ ${ }^{3}$ University of Alabama Facilities Department, 1205 14th Street, Tuscaloosa, AL 35487, USA
}

Correspondence should be addressed to Eric Marks; eric.marks@eng.ua.edu

Received 20 April 2016; Accepted 8 June 2016

Academic Editor: F. Pacheco-Torgal

Copyright (C) 2016 Carrie Pope et al. This is an open access article distributed under the Creative Commons Attribution License, which permits unrestricted use, distribution, and reproduction in any medium, provided the original work is properly cited.

\begin{abstract}
Renovation of an existing building is an accomplished stem of the construction industry because it supplies financial diversification for construction stakeholders. Although several construction planning tools and stakeholder alignment exercises have been developed, no tool exists to assist project owners to decide between renovating an existing building and new construction with a comprehensive decision criteria. The objective of this research is to create and test a renovation versus new building support decision tool for construction project stakeholders. The renovation versus new building support decision tool was created based on an extensive review of existing support tools and construction industry needs. The created tool was implemented to evaluate decisions of educational facilities by university officials experienced in project management. Results show the tool was effective in identifying relevant topics for discussion and guiding a group of stakeholders through an exercise in decision-making. Specifically, the tool was implemented by construction management personnel for university facilities currently under construction to evaluate the decision to renovate an existing building or new construction. The main contribution of this research is a framework and support decision tool readily implementable for construction project stakeholders desiring to determine if renovation or new construction is the optimal path for their specific objectives.
\end{abstract}

\section{Introduction}

Renovation of an existing building is a successful branch of the construction industry because it provides financial diversification for construction stakeholders [1]. Building owners are often challenged with deciding between new construction and renovating an existing building to achieve their desired scope [2]. This complex decision can impact the overall project budget, schedule, and quality.

Previous research efforts have identified that support is needed for construction decision-making [3]. Several tools and activities have been created to assist construction stakeholders when planning and making decisions $[4,5]$. However, none of these tools specifically support construction project owners tasked of selecting either new construction or renovation of an existing building. The objective of this research was to create a decision-making tool that supports construction project owners to aid in determining between renovating an existing building and new construction. The scope of this project included all construction-related ventures in which some information is known about the project purpose and project owners are deciding between renovation of an existing building and new construction.

A review of a sampling of construction decisions support tools was conducted, specifically tools implemented for project planning. Reviewing findings were used to create a renovation versus new building decision tool. This created decision tool was implemented to evaluate recent "renovation and new construction" decisions made by a university concerning educational facilities. A subsequent discussion of the analyzed research findings, encountered benefits and limitations, and envisioned future research work for decisionmaking support in the construction industry follows. 


\section{Background}

During a recession or decreasing economic situation, the construction industry often transitions from new construction projects to renovating an existing building [6]. The construction industry has utilized renovation projects as a method of diversification to remain profitable during a down economy [1]. Project owners are often required to decide between renovation of an existing building or new construction.

2.1. Support for Decision-Making. It has been theorized that decisions are a function of a person's resources, goals, and orientations [7]. In general, decision-making is a complex process due to unforeseen events, risk, and uncertainty [8]. Many tools, criteria, and processes have been created to support theoretical and applied decision-making. For example, the analytical hierarchy process provides a structured system for analyzing complex decisions which has been implemented in many industries [9]. This process has been used in many capacities including topography changes [10] and contractor selection [11]. Other created analytical tools implement planning matrices to optimize decision-making outcomes [12].

Education administrative personnel over facilities and project management have benefitted from decision-making support tools. This includes the creation of an optimization database to collect and analyze teacher inquiry and reflection concerning student data [13] as well as the implementation of a school-wide positive behavior support evaluation tool for trending student behavior [14]. The success of a school or school district can be linked to decisions made by administrators [15]. The rational model and bounded rationality model have been implemented to support decisionmaking by school administrators [15]. School boards in Michigan integrate analytical decision-making optimization to determine the demand for educational facilities based on community surveys, demographic data, and selected local plans [16].

2.2. Construction Project Decision-Making. A multitude of research conducted by the construction industry and academics has contributed to decision-making processes and prediction models for construction. Dominant factors in the decision to renovate or build new construction include investment cost and future market value of the existing building [17]. Due to the economic implications, several processes and decision tools have been developed to guide and support stakeholders during decision-making. These processes and tools enable construction project stakeholders to align on specific requirements and support the personnel during a decision-making process.

One such area that requires complex decision-making in construction project planning is sustainability, specifically energy consumption $[18,19]$. Energy consumption in existing houses was explored to understand why individuals decide to renovate their utilities [20]. Various decision criteria (e.g., exterior building materials) were evaluated in regard to life cycle implications of building renovations and new construction [21, 22]. In general, renovation-based strategies were found to have less of an environmental impact when compared to newly constructed houses with similar characteristics [23]. Four complex decisions were evaluated for an individual planning to optimize the investment of sustainable renewable options for a house including maintenance only, renovation options with minor improvements, transformation with major adjustments, and a new building option [24].

Unlike operational energy as previously discussed, embodied energy occurs during the construction phase of a building [25]. The embodied energy makes up a considerable part of the total energy use in buildings [26]. Considerable amounts of energy are spent in the manufacturing processes and transportation of various building materials [27, 28]. Several decision support tools have been created to measure the environmental impacts of embodied energy including life cycle assessment of environmental impacts of building materials [29], optimization mapping of transportation [30], and specialized tools considering environmental impacts only to commercial buildings [31].

Many tools have been developed to provide performancebased assessment models of various building characteristics. For example, a rating model tool was created to measure the heat loss through external windows and walls [32]. Other energy assessment tools have been implemented to predict monthly energy uses of an individual building [33]. Tools have also been created and implemented regarding building safety. One such tool simulates a fire evacuation drill for building occupants to validate acceptable escape paths and durations [34].

In addition to sustainability elements, stakeholders are often tasked with deciding between renovation and new construction for historically significant buildings. Older building renovation can be more aesthetic and culturally significant but often cost much more than newly constructed buildings with the same desired function [35]. Sociological researchers strive to preserve historical buildings as a means to better understand the logics of movement of a people group and conserve a collective memory of a community [36].

Although renovations of historically significant buildings are in high demand, structural engineers often encounter costly design challenges [37]. The balance between historical significance, building functionality, and economics presents unique challenges when deciding between renovation and new construction. Several research and private sector efforts have focused on improving renovation techniques for historically significant buildings including using timber-concrete composite structures to renovate historical wooden floors [38], an appraisal method to capture energy efficiency improvements from building renovation [18], and techniques to model human dynamic loads on structural floor vibrations of historical buildings [39].

2.3. Construction Project Scope Decisions. Construction project stakeholders typically decide between renovation and new construction during the initial scope planning phase. Developing a project scope for design includes many challenges including stakeholder alignment, defining the intended goal of the project and budget constraints [40]. 
The success of construction projects is largely dependent on the agreement of project stakeholders on the project scope [41, 42]. Managing uncertainty and aligning stakeholder interest during this scope planning phase are critical for stakeholders to determine if they desire to renovate an existing building or new construction [3].

2.4. Construction Project Decision Support Tools. Because of the uniqueness of construction projects and potentially complex scopes, many project decision support tools have been created and implemented by construction industry. Specifically, project decisions tools geared towards renovation have been implemented in an attempt to empower stakeholders to manage complex issues. An automated model with a complex set of interdependent attributes was created to measure the functional condition of building before and after a planned renovation [43]. A more specific decision model evaluated the anticipated energy performance improvement of a newly renovated office building [44]. Many other similar models were created for decisions within the realm of renovating an existing building including semiautomated selection of renovation alternatives [45], multicriteria "knapsack" model for renovation [46], and multicriteria renovation decisionmaking models $[47,48]$. These decision support tools only address building renovation elements and do not assist in decisions between renovating an existing building or constructing a new one.

2.5. Research Needs Statement. Project stakeholders are required to evaluate many criteria when deciding to renovate an existing building or to build new construction including economic success, intended functionality, and historical significance. Although a multitude of construction support decision tools and processes exist, none address the complexity of deciding between these two project scopes. The reviewed renovation decision models address only renovation and are often too ill-defined to include elements of new construction. A need exists for a decision support tool for stakeholders determining between renovation of an existing building and new construction.

\section{Materials and Methods}

Based on the results of the review and the stated research objective, the following steps were devised and completed: (1) review of existing construction planning decision support tools, (2) identification of decision support tool criteria, and (3) design decision support tool. These steps served as the methodology for creating the renovation versus new building support decision tool. This section provides details for each step in the research methodology.

3.1. CII Project Definition Rating Index (PDRI). Past research efforts have produced strategies and devices to support construction planning decision-making. A multitude of these research deliverables were investigated for their benefits and limitations with regard to construction stakeholders making decisions. Some of the most used tools are shown in Table 1 with their objectives and limitations.
The Construction Industry Institute (CII) created a decision support tool called the Project Definition Rating Index (PDRI) which attempts to align stakeholder interest and accurately define the project scope during the preplanning phase [52]. This tool uses a weighted checklist of 64 scope definition elements for stakeholder evaluation of the given project [52]. By using this tool, project stakeholders can identify and communicate areas of uncertainty before construction begins [53]. The success of the PDRI can be measured by the outgrowths of PDRI tools for specific categories including the PDRI for sustainable building projects [54].

Several iterations of the PDRI have been completed to broaden the scope of the PDRI concept and to refine the process. CII has framed the PDRI for building projects and industrial projects [49]. Principles of front-end planning were also established for renovation and revamp projects by CII $[55,56]$. Research findings and corresponding best practices from both CII's PDRI and work in front-end planning established the foundational elements for the created renovation versus new building support decision tool.

3.2. Criteria for Decision Support Tool. A set of criteria for the decision support tool was identified based on the results of the construction planning decision support tool review. To compile the set of categories for the decision support tool, existing construction planning decision support tools were reviewed as discussed in the previous section. All criteria relevant to deciding between renovation of an existing building and new construction were included. Users of the tool are able to modify existing decision criteria or add new criteria as needed for their specific project. Project metrics, such as cost, are represented in terms of level of effort. Each criteria category provides a definition of level of effort for scoring the metrics.

The following sections were identified to assist in deciding between renovation of an existing building or new construction: (1) planning, (2) facilities management, (3) project requirements, (4) site considerations, and (5) project design parameters. The categories were identified based on the review of existing construction planning decision support tools and review by three experienced university facilities construction personnel. All criteria elements were divided into categories in an attempt to increase the effectiveness of the tool and to foster discussion among similar topics between the project stakeholders. Each of these categories has between four and six specific categories for evaluation by the tool users. Table 2 presents a description of each category and potential elements to be evaluated within the planning section. The project stakeholders will discuss each category and score their perceived level of effort for either constructing new or renovating an existing building for each individual category. For example, members using the tool will estimate if the overall level of effort for project validation, category 2, will require more effort if a new building is constructed or if the existing building is renovated.

Table 3 presents a description of each category and potential elements to be evaluated within the facilities management section. 
TABLE 1: Review of existing strategic business planning tools.

\begin{tabular}{lll}
\hline Tool type & Objective & Limitation \\
\hline $\begin{array}{l}\text { Multidimensional site management } \\
\text { model [49] }\end{array}$ & $\begin{array}{l}\text { Integrating 4D technology to solve } \\
\text { problems of construction resource } \\
\text { planning }\end{array}$ & $\begin{array}{l}\text { It only addresses resource management } \\
\text { and site space utilization }\end{array}$ \\
\hline $\begin{array}{l}\text { Virtual design for preconstruction } \\
\text { planning [50] }\end{array}$ & $\begin{array}{l}\text { Utilizing virtual reality modeling } \\
\text { techniques to create the virtual planning } \\
\text { tool for construction applications }\end{array}$ & $\begin{array}{l}\text { Tool is a prototype and has not been } \\
\text { tested for actual construction situations }\end{array}$ \\
\hline $\begin{array}{l}\text { Simulation modeling and geographic } \\
\text { information system [51] }\end{array}$ & $\begin{array}{l}\text { Creation of spatial support system design } \\
\text { tool to evaluate contingency planning for } \\
\text { emergency evacuation }\end{array}$ & $\begin{array}{l}\text { It fails to address the financial side of } \\
\text { construction project planning }\end{array}$ \\
\hline $\begin{array}{l}\text { Computer-aided planning support } \\
\text { systems for construction [5] }\end{array}$ & $\begin{array}{l}\text { Implementing computer-based } \\
\text { geoinformation instruments as a subset of } \\
\text { established planning support systems }\end{array}$ & $\begin{array}{l}\text { It lacks specific criteria to decide between } \\
\text { renovation construction projects and new } \\
\text { buildings }\end{array}$ \\
\hline
\end{tabular}

TABLE 2: Planning section categories of decision support criteria.

\begin{tabular}{ll}
\hline $\begin{array}{l}\text { Description } \\
\text { Elements }\end{array}$ & $\begin{array}{l}\text { Desired functionality of the proposed building } \\
\text { Institutional, medical, research, food service, multimedia, recreational, office, retail, instructional, mass transit, } \\
\text { and residential }\end{array}$ \\
\hline $\begin{array}{l}\text { Description } \\
\text { Elements }\end{array}$ & $\begin{array}{l}\text { Determining the levels of importance based on project requirements and expectations } \\
\text { Sustainability considerations, end user considerations, modifications needed to meet regulatory requirements, } \\
\text { usage rationalization, amenities, and site location (e.g., LEED rating systems, LBC certification, and Envision } \\
\text { Sustainable Infrastructure Rating System) }\end{array}$ \\
\hline $\begin{array}{l}\text { Description } \\
\text { Elements }\end{array}$ & $\begin{array}{l}\text { Category 3: project costs } \\
\text { Available funding, types and sources of project funds, cost and financing, and related/resulting projects }\end{array}$ \\
\hline $\begin{array}{l}\text { Description } \\
\text { Elements }\end{array}$ & $\begin{array}{l}\text { Assessing the level of effort required to achieve the desired project schedule } \\
\text { Proposed project end date, schedule milestones and deadlines, and related/resulting projects }\end{array}$ \\
\hline $\begin{array}{l}\text { Description } \\
\text { Elements }\end{array}$ & $\begin{array}{l}\text { Assessing the level of effort required for a new building or existing building to meet size requirements } \\
\text { Usage adaptability, classroom size, occupancy, market capacity, volume, area uses in net and gross surface area, } \\
\text { number of laboratory stations, linear feet or display space, occupant accommodation requirements, operational } \\
\text { security system requirements, and antiterrorism standards }\end{array}$ \\
\hline
\end{tabular}

Table 4 presents a description of each category and potential elements to be evaluated within the project requirements section.

Table 5 presents a description of each category and potential elements to be evaluated within the site considerations section.

Table 6 presents a description of each category and potential elements to be evaluated within the project design parameters section.

To increase the effectiveness of this construction decision support tool, members of the group completing the tool (i.e., university project management administrative personnel) were encouraged to integrate previously used preplanning tools into this process. For example, to achieve a more detailed and accurate sustainability rating, users are encouraged to implement existing tools such as the Leadership in Energy and Environmental Design (LEED) ratings systems
[57], the Living Building Challenge (LBC) certification [58], and the Envision Sustainable Infrastructure Rating System [59].

3.3. Renovation versus New Building Support Decision Tool. The renovation versus new building support decision tool was created as an interface to allow group members to interact with the decision criteria. Furthermore the tool provides automated analysis and assessment of input data provided by the group members. Each category of criteria was constructed on an individual page with instructions on how to assess each decision criteria. Programmable functions embedded in Microsoft Excel were used to construct the user interfaces for each category of design criteria. A hidden spreadsheet records all group member responses and automatically calculates overall scores for each category of decision criteria. The interface of automated spreadsheet was selected due to 
TABLE 3: Facilities management section categories of decision support criteria.

\begin{tabular}{|c|c|}
\hline \multicolumn{2}{|r|}{ Category 1: performance reliability } \\
\hline Description & Assessing the level of effort needed to accomplish optimal operational performance from the desired building \\
\hline Elements & $\begin{array}{l}\text { Critical systems redundancy, architectural stability, structural stability, civil stability and reliability of } \\
\text { mechanical, and electrical and plumbing systems }\end{array}$ \\
\hline \multicolumn{2}{|r|}{ Category 2: maintenance requirements } \\
\hline Description & Evaluating the level of effort requirements needed to meet the requirements of the maintenance \\
\hline Elements & $\begin{array}{l}\text { Daily occupancy loads, maximum occupancy requirements, equipment monitoring requirements, materials, } \\
\text { finishes, commissioning plans, maintenance impact, and compatibility with existing maintenance }\end{array}$ \\
\hline \multicolumn{2}{|r|}{ Category 3: design issues } \\
\hline Description & Considering design issues and the level of effort needed to meet these issues \\
\hline Elements & Layout flexibility, design life, aesthetics, master plan compatibility, and overall size of building \\
\hline \multicolumn{2}{|r|}{ Category 4: building level of service } \\
\hline Description & Assessing the level of performance for the desired building in terms of space planning and functionality \\
\hline Elements & $\begin{array}{l}\text { Outline of desired goals of building performance, an achievable level of service, and an acceptable approach to } \\
\text { establish project criterion }\end{array}$ \\
\hline \multicolumn{2}{|r|}{ Category 5: envisioned post occupancy } \\
\hline Description & $\begin{array}{l}\text { Evaluation of building from current users of the building to identify necessary improvements in building design } \\
\text { and performance and to assess the overall building scope }\end{array}$ \\
\hline Elements & $\begin{array}{l}\text { Postoccupancy evaluation, retrocommissioning and perceived productivity studies, and end-of-life cycle } \\
\text { considerations }\end{array}$ \\
\hline
\end{tabular}

TABLE 4: Project requirements section categories of decision support criteria.

\begin{tabular}{|c|c|}
\hline & Category 1: economic feasibility \\
\hline Description & $\begin{array}{l}\text { Assessing the cost effectiveness of the design and material alternatives for the renovation and considering items } \\
\text { that impact the economics of the project }\end{array}$ \\
\hline \multirow[t]{2}{*}{ Elements } & Overall project scope, construction material cost, construction methods, and economics of sustainable design \\
\hline & Category 2: evaluation of capacity \\
\hline Description & Performing an assessment to determine if the desired building will meet requirements of capacity \\
\hline \multirow[t]{2}{*}{ Elements } & $\begin{array}{l}\text { Power, water, telecommunications, storm water, waste water, water filtration, sanitary sewer, parking areas, } \\
\text { roads, construction access, ambulance access, and medical facilities }\end{array}$ \\
\hline & Category 3: existing building \\
\hline Description & Rating the level of effort required to address the existing building \\
\hline \multirow[t]{2}{*}{ Elements } & Layout, capacity to accommodate desires, structural grid, and structural integrity \\
\hline & Category 4: existing mechanical, electrical, and plumbing (MEP) systems \\
\hline Description & Assessing the level of effort to address the existing mechanical, electrical, and plumbing (MEP) systems \\
\hline \multirow[t]{2}{*}{ Elements } & $\begin{array}{l}\text { Heating and cooling systems, large motors, thermal distribution, water heating, water cooling, lighting fixtures, } \\
\text { lighting controls, meters, electrical circuits, and plumbing fixtures and connections }\end{array}$ \\
\hline & Category 5: existing exterior features \\
\hline Description & Rating the level of effort to address building envelope features both for demolition and for renovation. \\
\hline \multirow[t]{2}{*}{ Elements } & Windows, doors, insulation, roofing, underground utilities, embedded structures, and archeological survey \\
\hline & Category 6: existing interior equipment \\
\hline Description & $\begin{array}{l}\text { Identifying the utility impact of equipment, moveable furnishings, and desired built-ins and the resulting level } \\
\text { of work effort required for each }\end{array}$ \\
\hline Elements & $\begin{array}{l}\text { Moveable furniture, kitchen equipment, medical equipment, material handling, partitions, and refurbished } \\
\text { items }\end{array}$ \\
\hline
\end{tabular}

its effectiveness in existing construction planning decision support tools including CII's PDRI [52].

It is recommended that project owners faced with deciding between renovation of an existing building or new construction complete the tool as a group. Members of the group should include any university administrative or construction personnel with a vested interest in the project planning phase (e.g., university construction management personnel, university dean of facilities, and university financial supervisor). The group should read and assess each category description 
TABLE 5: Site considerations section categories of decision support criteria.

\begin{tabular}{|c|c|}
\hline \multicolumn{2}{|r|}{ Category 1: initial survey of site } \\
\hline Description & Determining the level of effort needed to address items requiring attention in the site survey \\
\hline Elements & $\begin{array}{l}\text { Easements, right-of-way, drainage patterns, elevations, benchmark control systems, elevations, access and curb } \\
\text { cuts, proximity to drainage ways, flood plains, below grade structures and utilities, trees and vegetation, existing } \\
\text { building locations and conditions, wetlands, and mass transit }\end{array}$ \\
\hline \multicolumn{2}{|r|}{ Category 2: geotechnical survey } \\
\hline Description & $\begin{array}{l}\text { Evaluating the existing geotechnical site and determining the level of work effort to improve items needing } \\
\text { attention from survey }\end{array}$ \\
\hline Elements & $\begin{array}{l}\text { Depth to bedrock, site description, soil potential, fault line locations, spoil area for excess soil, seismic } \\
\text { requirements, water table elevation, floor plain analysis, ground water, bearing capacities, paving design } \\
\text { options, and overall site analysis }\end{array}$ \\
\hline \multicolumn{2}{|r|}{ Category 3: regulatory permits } \\
\hline Description & Assessing the level of effort needed to meet requirements \\
\hline Elements & $\begin{array}{l}\text { Construction, signage, environmental, historical issues, accessibility, demolition, setback, fire, building } \\
\text { occupancy, transportation, and antiterrorism standards }\end{array}$ \\
\hline \multicolumn{2}{|r|}{ Category 4: environmental impact } \\
\hline Description & Performing environmental assessment to define the level of effort needed to improve issues found \\
\hline Elements & $\begin{array}{l}\text { Archeological and environmental permits, existing contamination, ground water monitoring, existing } \\
\text { problems, noise/vibration requirements, detention requirements, and erosion/sediment control }\end{array}$ \\
\hline \multicolumn{2}{|r|}{ Category 5: worker safety } \\
\hline Description & $\begin{array}{l}\text { Taking into account fire and life safety related items to determine the level of effort necessary to improve or } \\
\text { implement the proper requirements }\end{array}$ \\
\hline Elements & $\begin{array}{l}\text { Fire monitors and hydrants, access and evacuation plan, emergency medical building availability, security } \\
\text { considerations, and onsite medical care }\end{array}$ \\
\hline
\end{tabular}

TABLE 6: Project design parameters section categories of decision support criteria.

\begin{tabular}{|c|c|}
\hline \multicolumn{2}{|r|}{ Category 1: civil building design } \\
\hline Description & Considering the desired civil building design to determine the level of work needed to reach the design criteria \\
\hline Elements & $\begin{array}{l}\text { Service and storage necessities, site utilities, earthwork, subsurface work, elevation and profile views, equipment } \\
\text { location, paving/curbs, landscape, fencing/site security, storm drainage system, underground utilities location } \\
\text { and route, minimum overhead clearances, and design for safety }\end{array}$ \\
\hline \multicolumn{2}{|r|}{ Category 2: interior building design } \\
\hline Description & $\begin{array}{l}\text { Addressing the interior building design issues and recognizing the necessary level of effort to reach the desired } \\
\text { design criteria }\end{array}$ \\
\hline Elements & $\begin{array}{l}\text { Building requirements, accessibility requirements, character of building design, construction materials, } \\
\text { acoustical considerations, planning and zoning review boards, circulation considerations, technological } \\
\text { sophistication, color/material and hardware standards, furnishings criteria, design grid, and reuse of equipment }\end{array}$ \\
\hline \multicolumn{2}{|r|}{ Category 3: structural characteristics } \\
\hline Description & Determining the structural design issues and the level of effort needed to meet the desired criteria \\
\hline Elements & $\begin{array}{l}\text { Structural system, foundation system, future expansion/flexibility considerations, design load parameters, } \\
\text { corrosion control, protective coating requirements, and functional spatial constraints }\end{array}$ \\
\hline \multicolumn{2}{|r|}{ Category 4: mechanical/electrical/plumbing characteristics } \\
\hline Description & $\begin{array}{l}\text { Developing mechanical and electrical design parameters and rating the level of effort necessary to meet the } \\
\text { desired design criteria }\end{array}$ \\
\hline Elements & $\begin{array}{l}\text { Equipment life cycle costs, energy conservation, consumption and life cycle cost, zoning and controls, air } \\
\text { circulation requirements, design conditions, building emissions, system redundancy conditions, plumbing } \\
\text { requirements, fire protection, alternate energy systems, lighting considerations, outdoor lighting, and } \\
\text { emergency power requirements }\end{array}$ \\
\hline \multicolumn{2}{|r|}{ Category 5: building user safety } \\
\hline Description & Rating the level of work effort needed to meet all safety requirements for building operations \\
\hline Elements & $\begin{array}{l}\text { Fire and explosion resistance, area of refuge, safety and alarms, hazardous materials treatment, emergency } \\
\text { equipment, shelters, egress, and disaster communications }\end{array}$ \\
\hline
\end{tabular}




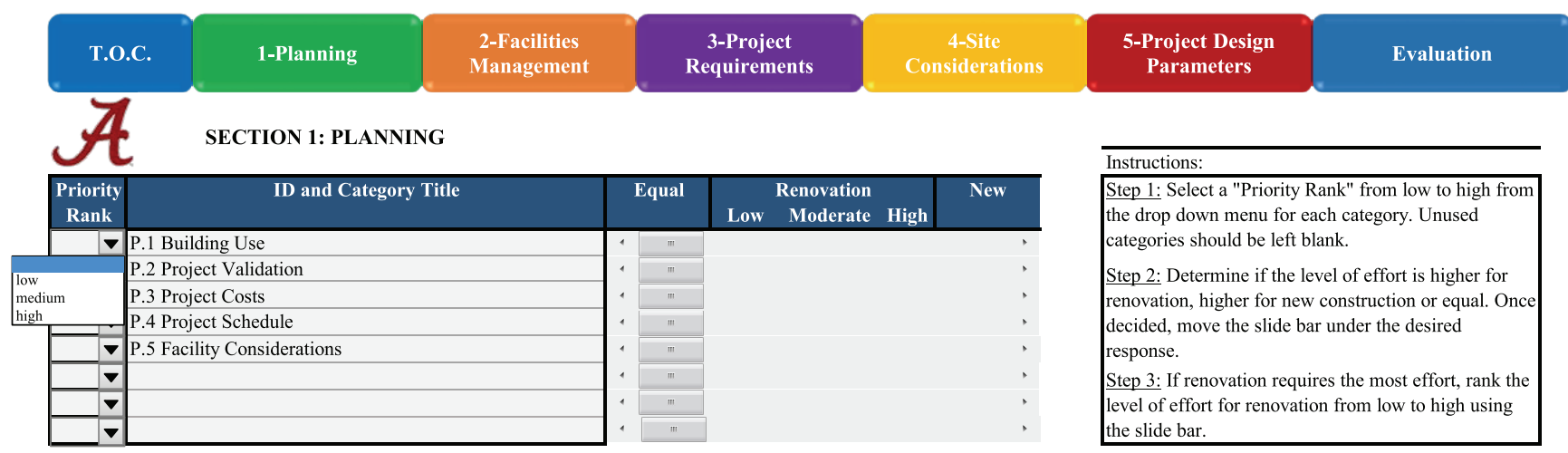

FIGURE 1: User interface for planning section of decision support tool.

and element listing. The group members should specifically estimate the level of effort required for each category. Level of effort encompasses perceived cost, scheduling issues, constructability, and desired quality. Desired quality is the perceived level of quality for each stakeholder using the tool of the project under review. It is assumed that if an existing building is thought to be potentially renovated, the demolition of this building is not under consideration with the created decision tool. However, the demolishing of an existing building can be factored into the decision tool as an additional set of criteria by the user.

A commonly used database software (Microsoft Excel) was used to house the decision tool. All functionality of the decision tool including the user interface and scoring equations were created to function in the database software. Users navigate a series of tabs by means of a hyperlinked control panel. The first page provides user directions and an outline of the tool components. The remaining tabs include categories for each section and an evaluation tab that summarizes the user scoring results. Each tab provides a list of instructions and description of each category to be assessed. The planning section tab is on display in Figure 1.

For each category, the group will first prioritize each category scored as "low," "medium," or "high." This prioritization assigns a weight to each individual category. The left side of Figure 1 shows the prioritization pull-down menu. The group will then determine the level of effort for each category. The group should estimate the level of effort to decide between the following options.

(1) The level of effort is equal between renovation of an existing building and new construction.

(2) The level of effort for renovation is greater than building new construction. If this is the case, the group must decide if the renovation level of effort is "low," "moderate," or "high" compared to past renovation ventures.

(3) The level of effort for building new construction is greater than renovation.

The group must use the slide bar to score each assessment for each category. The group should complete this process for each category within each section. Once completed, the evaluation tab shows the resulting score of the group's assessment. The displayed score shows the rating for each section as well as the overall group level of effort rating. The lowest score reveals the best options for the project under investigation because it represents the lowest level of effort between renovation of an existing building and new construction. Figure 2 presents a sample scoring tab after a group assessment. Based on the sample scoring shown, the groups should focus on renovation because the level of effort is lower.

\section{Results and Discussion}

The created renovation versus new building support decision tool was implemented on two active construction projects on the University of Alabama's campus in Tuscaloosa, Alabama. Both projects are existing campus facilities under renovation by local contractors. The motivation to create this decisionmaking support tool was formed from a lack of structured decision criteria and process for determining between new construction and renovation of an existing building. Both buildings (Buildings A and B) were educational buildings that recently underwent renovation.

Project managers and other facilities personnel at the University of Alabama were asked to assess the level of effort of each project based on the project specifications and overall scope. Two project management personnel for each project completed the renovation versus new building support decision tool for their corresponding project. All four individuals were the current supervising project managing representative for the university and each had greater than 5 years of experience in that position. Each individual has previous project experience at the university in which they participated in the project planning process. Furthermore, each individual had obtained either an engineering or a construction management degree. The maximum amount of time required by the research participants was 2 hours to complete the tool with an average duration of 1.7 hours. Table 7 presents the assessment of facilities personnel for two existing renovation projects.

The overall level of effort score was lower for renovation in both projects shown in Table 7. The resulting level of 
TABLE 7: Scoring summary of facilities personnel for existing construction projects.

\begin{tabular}{|c|c|c|c|c|c|c|c|}
\hline & & Planning & $\begin{array}{c}\text { Facilities } \\
\text { management }\end{array}$ & $\begin{array}{c}\text { Project } \\
\text { requirements }\end{array}$ & $\begin{array}{c}\text { Site } \\
\text { considerations }\end{array}$ & $\begin{array}{c}\text { Project design } \\
\text { parameters }\end{array}$ & Overall \\
\hline \multirow{2}{*}{ Building A } & New construction & 67 & 56 & 36 & 43 & 60 & 52 \\
\hline & Renovation & 33 & 44 & 64 & 57 & 40 & 48 \\
\hline \multirow{2}{*}{ Building B } & New construction & 90 & 69 & 63 & 38 & 55 & 63 \\
\hline & Renovation & 10 & 31 & 37 & 63 & 45 & 37 \\
\hline
\end{tabular}

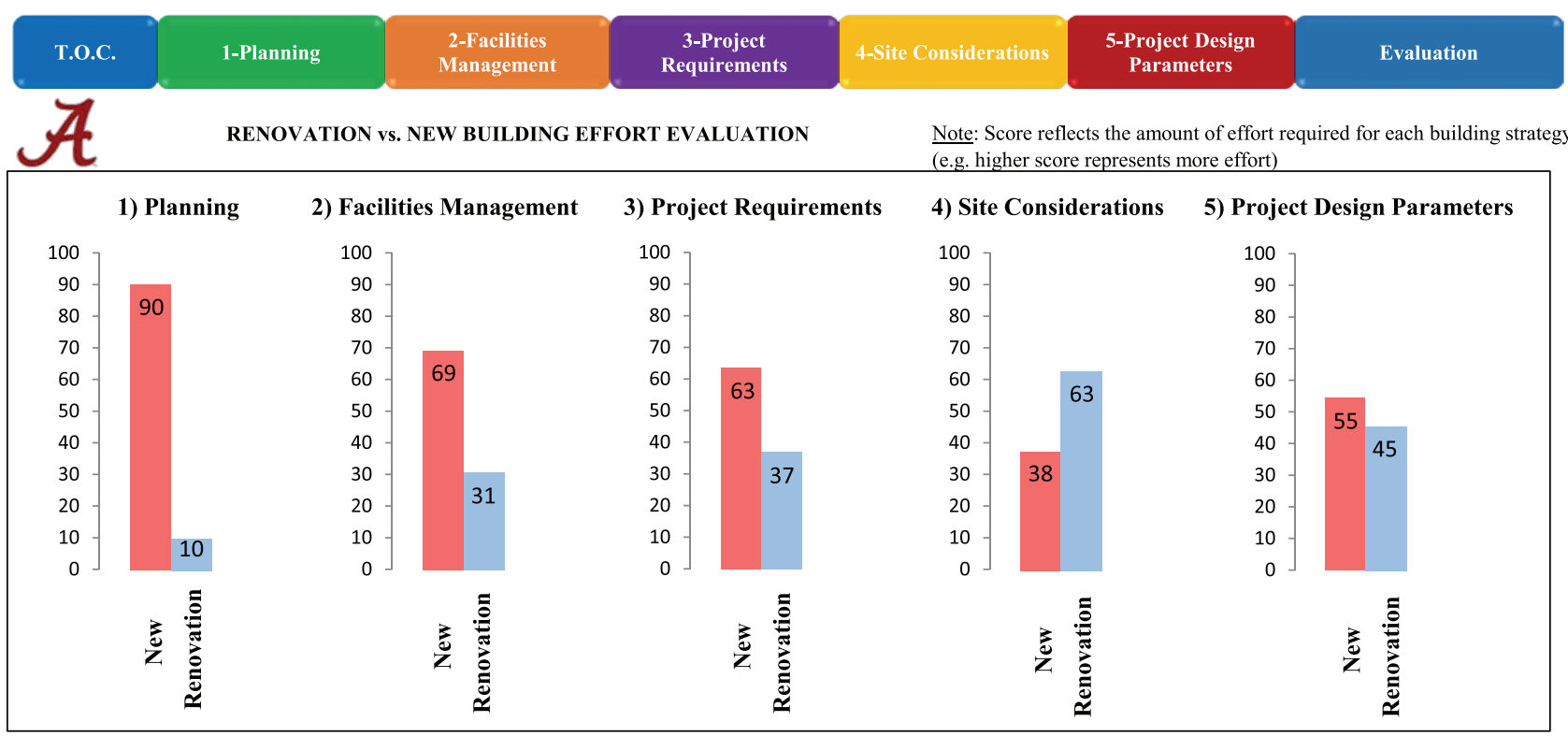

Overall Effort Score

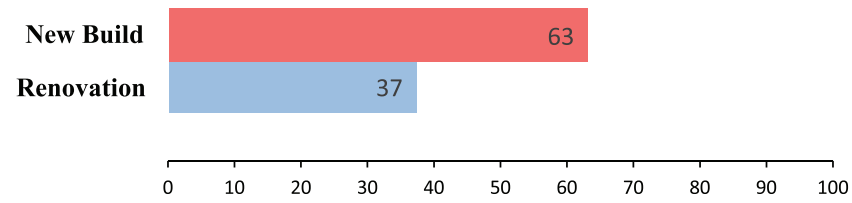

FIGURE 2: Section and overall scoring summary of decision tool.

effort score was representative of the actual decisions made by project stakeholders because both projects are renovation projects. For Building A, the level of effort was lower for all categories except project requirements and site considerations. The assessment group indicated issues of cost and state of the existing building and interior equipment led to the increased renovation level of effort scores in these categories. Likewise, all categories except site considerations were ranked with higher levels of effort for new construction than renovation for Building B. Scorers indicated that the environmental and historical issues associated with renovation required a higher level of effort than new construction. Although group members are able to modify weighting for certain criteria based on their perception of the project, the four project participants decided that all criteria were equally important and declined to modify the criteria weights. By implementing the tool for active construction renovation projects on the university campus, an external validation was executed because all project participants selected renovation as the lower amount of effort when compared to new construction. Additionally, an internal validation effort was completed on the tool by selecting each user input option individually and accessing the tool's response. This effort affirmed the robustness of the tool's functions and capabilities.

\section{Conclusions}

The decision to renovate or build new construction by project owners can greatly impact the overall project budget, schedule, and quality of construction. Although a variety of industry and academic research have resulted in processes and tools for making decisions in construction, there is a need for a tool to aid owners when deciding between renovation of an existing building and new construction.

A renovation versus new building support decision tool was created to support project owners when making 
this decision. The tool was created based on results of a review of existing construction decisions support tools and construction stakeholder needs in preproject planning and project scope decisions. The renovation versus new building support decision tool was implemented to evaluate decisions of two currently renovated educational buildings by university construction project managers. Research results indicate that the tool can be effective in supporting project stakeholders when deciding between renovating an existing building or new construction. The main research contribution is a framework and an automated support decision tool for construction stakeholders deciding between renovation of existing buildings and new construction. The research also contributes scientific evaluation data for the created tool implemented into two existing renovation construction projects for assessment.

Limitations of this work were the generalization of level of effort when compared to the variety of available project controls (e.g., scheduling, productivity, safety, and quality). Future decision support tools could integrate more detailed specifications of quality, cost, scheduling, constructability, and others to more accurately support the decision. Due to the drastic benchmark ranges of construction project controls, level of effort was selected to allow project owners to consider all project controls. Future research could also integrate other construction project support tools with the renovation versus new building support decision tool.

\section{Competing Interests}

The authors declare that they have no competing interests.

\section{References}

[1] T. Nistorescu and C. Ploscaru, "Impact of economic and financial crisis in the construction industry," Management and Marketing-Craiova, vol. 1, no. 1, pp. 25-36, 2010.

[2] M. Keymer, Design strategies for new and renovation construction that increase the capacity of buildings to accommodate change [Ph.D. dissertation], Massachusetts Institute of Technology, 2000.

[3] R. Atkinson, L. Crawford, and S. Ward, "Fundamental uncertainties in projects and the scope of project management," International Journal of Project Management, vol. 24, no. 8, pp. 687-698, 2006.

[4] C.-S. Cho and G. E. Gibson Jr., "Building project scope definition using project definition rating index," Journal of Architectural Engineering, vol. 7, no. 4, pp. 115-125, 2001.

[5] S. Geertman and J. Stillwell, "Planning support systems: an inventory of current practice," Computers, Environment and Urban Systems, vol. 28, no. 4, pp. 291-310, 2004.

[6] S. Carlson, "Recession slows new building, but renovations a bright spot for construction contractors," 2010, http://financecommerce.com.

[7] A. Schoenfeld, How we Think: A Theory Of Goal-Oriented Decision Making and its Educational Applications, Routledge, New York, NY, USA, 2011.

[8] B. Wiley, Analysis and Decision Making in Uncertain Systems, Springer, New York, NY, USA, 2003.
[9] R. Handfield, S. V. Walton, R. Sroufe, and S. A. Melnyk, "Applying environmental criteria to supplier assessment: a study in the application of the Analytical Hierarchy Process," European Journal of Operational Research, vol. 141, no. 1, pp. 7087, 2002.

[10] A. Yalcin, "GIS-based landslide susceptibility mapping using analytical hierarchy process and bivariate statistics in Ardesen (Turkey): comparisons of results and confirmations," Catena, vol. 72, no. 1, pp. 1-12, 2008.

[11] P. S.-W. Fong and S. K.-Y. Choi, "Final contractor selection using the analytical hierarchy process," Construction Management and Economics, vol. 18, no. 5, pp. 547-557, 2000.

[12] M. David, F. David, and F. David, "The Quantitative Strategic Planning Matrix (QSPM) applied to a retail computer store," Coastal Business Journal, vol. 8, no. 1, pp. 42-52, 2009.

[13] J. C. Wayman, "Involving teachers in data-driven decision making: using computer data systems to support teacher inquiry and reflection," Journal of Education for Students Placed at Risk, vol. 10, no. 3, pp. 295-308, 2005.

[14] R. H. Horner, A. W. Todd, T. Lewis-Palmer, L. K. Irvin, G. Sugai, and J. B. Boland, "The school-wide evaluation tool (SET): a research instrument for assessing school-wide positive behavior support," Journal of Positive Behavior Interventions, vol. 6, no. 1, pp. 3-12, 2004.

[15] F. Lunenburg, “The decision making process," National Forum of Educational Administration and Supervision Journal, vol. 27, no. 4, pp. 1-12, 2010.

[16] R. K. Norton, "Planning for school facilities: school board decision making and local coordination in Michigan," Journal of Planning Education and Research, vol. 26, no. 4, pp. 478-496, 2007.

[17] M. Morelli, M. Harrestrup, and S. Svendsen, "Method for a component-based economic optimisation in design of whole building renovation versus demolishing and rebuilding," Energy Policy, vol. 65, pp. 305-314, 2014.

[18] V. Martinaitis, E. Kazakevičius, and A. Vitkauskas, "A twofactor method for appraising building renovation and energy efficiency improvement projects," Energy Policy, vol. 35, no. 1, pp. 192-201, 2007.

[19] B. P. Goldstein, M. Herbøl, and M. J. Figueroa, "Gaps in tools assessing the energy implications of renovation versus rebuilding decisions," Current Opinion in Environmental Sustainability, vol. 5, no. 2, pp. 244-250, 2013.

[20] K. Gram-Hanssen, "Existing buildings-users, renovations and energy policy," Renewable Energy, vol. 61, pp. 136-140, 2014.

[21] B. Dong, C. Kennedy, and K. Pressnail, "Comparing life cycle implications of building retrofit and replacement options," Canadian Journal of Civil Engineering, vol. 32, no. 6, pp. 10511063, 2005.

[22] L. Užšilaityte and V. Martinaitis, "Search for optimal solution of public building renovation in terms of life cycle," Journal of Environmental Engineering and Landscape Management, vol. 18, no. 2, pp. 102-110, 2010.

[23] L. Itard and G. Klunder, "Comparing environmental impacts of renovated housing stock with new construction," Building Research and Information, vol. 35, no. 3, pp. 252-267, 2007.

[24] O. Ortiz, F. Castells, and G. Sonnemann, "Sustainability in the construction industry: a review of recent developments based on LCA," Construction and Building Materials, vol. 23, no. 1, pp. 28-39, 2009. 
[25] M. K. Dixit, J. L. Fernández-Solís, S. Lavy, and C. H. Culp, "Identification of parameters for embodied energy measurement: a literature review," Energy and Buildings, vol. 42, no. 8, pp. 12381247, 2010.

[26] C. Thormark, "A low energy building in a life cycle-its embodied energy, energy need for operation and recycling potential," Building and Environment, vol. 37, no. 4, pp. 429-435, 2002.

[27] B. V. Venkatarama Reddy and K. S. Jagadish, "Embodied energy of common and alternative building materials and technologies," Energy and Buildings, vol. 35, no. 2, pp. 129-137, 2003.

[28] G. P. Hammond and C. I. Jones, "Embodied energy and carbon in construction materials," Proceedings of Institution of Civil Engineers-Energy, vol. 161, no. 2, pp. 87-98, 2008.

[29] G. Menzies, S. Turan, and P. Banfill, "Life-cycle assessment and embodied energy: a review," Institute of Civil EngineersConstruction Materials, vol. 160, no. 4, pp. 135-143, 2007.

[30] J. M. Pearce, S. J. Johnson, and G. B. Grant, "3D-mapping optimization of embodied energy of transportation," Resources, Conservation and Recycling, vol. 51, no. 2, pp. 435-453, 2007.

[31] A. A. Guggemos and A. Horvath, "Decision-support tool for assessing the environmental effects of constructing commercial buildings," Journal of Architectural Engineering, vol. 12, no. 4, pp. 187-195, 2006.

[32] C. Tian, T. Chen, H. Yang, and T.-M. Chung, "A generalized window energy rating system for typical office buildings," Solar Energy, vol. 84, no. 7, pp. 1232-1243, 2010.

[33] T. Catalina, J. Virgone, and E. Blanco, "Development and validation of regression models to predict monthly heating demand for residential buildings," Energy and Buildings, vol. 40, no. 10, pp. 1825-1832, 2008.

[34] M. Kobes, I. Helsloot, B. De Vries, and J. G. Post, "Building safety and human behaviour in fire: a literature review," Fire Safety Journal, vol. 45, no. 1, pp. 1-11, 2010.

[35] R. Shipley, S. Utz, and M. Parsons, "Does adaptive reuse pay? A study of the business of building renovation in Ontario, Canada," International Journal of Heritage Studies, vol. 12, no. 6, pp. 505-520, 2006.

[36] M. J. Milligan, "Buildings as history: the place of collective memory in the study of historic preservation," Symbolic Interaction, vol. 30, no. 1, pp. 105-123, 2007.

[37] I. Erdem and D. B. Peraza, "Challenges in renovation of vintage buildings," Journal of Performance of Constructed Facilities, vol. 29, no. 6, Article ID 04014166, 2015.

[38] E. Steinberg, R. Selle, and T. Faust, "Connectors for timberlightweight concrete composite structures," Journal of Structural Engineering, vol. 129, no. 11, pp. 1538-1545, 2003.

[39] A. Ebrahimpour and R. L. Sack, "A review of vibration serviceability criteria for floor structures," Computers \& Structures, vol. 83, no. 28-30, pp. 2488-2494, 2005.

[40] E. Gibson and M. Pappas, "Starting smart: key practices for developing scopes of work for facility projects," Federal Facilities Council Technical Report 146, National Academies Press, Washington, DC, USA, 2003.

[41] A. F. Griffith and G. E. Gibson Jr., "Alignment during preproject planning," Journal of Management in Engineering, vol. 17, no. 2, pp. 69-76, 2001.

[42] L. Song and S. M. AbouRizk, "Quantifying engineering project scope for productivity modeling," Journal of Construction Engineering and Management, vol. 131, no. 3, pp. 360-367, 2005.
[43] P. Reddy, M. Sucur, and S. Ariaratnam, "Building renovation decision support model," in Computing in Civil and Building Engineering, pp. 1547-1554, 1993.

[44] Y.-K. Juan, P. Gao, and J. Wang, "A hybrid decision support system for sustainable office building renovation and energy performance improvement," Energy and Buildings, vol. 42, no. 3, pp. 290-297, 2010.

[45] Y. Rosenfeld and I. M. Shohet, "Decision support model for semi-automated selection of renovation alternatives," Automation in Construction, vol. 8, no. 4, pp. 503-510, 1999.

[46] K. Alanne, "Selection of renovation actions using multi-criteria 'knapsack' model," Automation in Construction, vol. 13, no. 3, pp. 377-391, 2004.

[47] M. Medineckiene and F. Björk, "Owner preferences regarding renovation measures - the demonstration of using multicriteria decision making," Journal of Civil Engineering and Management, vol. 17, no. 2, pp. 284-295, 2011.

[48] L. Tupenaite, E. K. Zavadskas, A. Kaklauskas, Z. Turskis, and M. Seniut, "Multiple criteria assessment of alternatives for built and human environment renovation," Journal of Civil Engineering and Management, vol. 16, no. 2, pp. 257-266, 2010.

[49] Y.-R. Wang and G. E. Gibson Jr., "A study of preproject planning and project success using ANNs and regression models," Automation in Construction, vol. 19, no. 3, pp. 341-346, 2010.

[50] A. F. Waly and W. Y. Thabet, "A virtual construction environment for preconstruction planning," Automation in Construction, vol. 12, no. 2, pp. 139-154, 2003.

[51] F. N. De Silva and R. W. Eglese, "Integrating simulation modelling and GIS: spatial decision support systems for evacuation planning," Journal of the Operational Research Society, vol. 51, no. 4, pp. 423-430, 2000.

[52] C. Cho and E. Gibson, "Development of a Project Definition Rating Index (PDRI) for general building projects," in Proceedings of the Construction Research Congress, pp. 343-352, 2000.

[53] P. Dumont, E. Gibson, and J. Fish, "Scope management using the project definition rating index," Journal of Construction Management Engineering, vol. 13, no. 5, pp. 54-60, 1997.

[54] G. Weerasinghe, K. Soundararajan, and J. Ruwanpura, "LEEDPDRI framework for pre-project planning of sustainable building projects," Journal of Green Building, vol. 2, no. 3, pp. 123-143, 2007.

[55] S. Howard, E. Gibson, D. Whittington, and Q. Cui, "Analysis supporting front end planning for renovation and revamp projects, part I," Report RR242, 2009.

[56] D. Whittington, E. Gibson, and Q. Cui, "Analysis supporting front end planning for renovation and revamp projects. Part 2," Tech. Rep. 242, 2008.

[57] U.S. Green Building Council, "LEED rating system. U.S. Green Building Council," 2015, http://www.usgbc.org/certification.

[58] International Living Future Institute, "Living building challenge," 2015, http://living-future.org/lbc.

[59] Institute for Sustainable Infrastructure, "Envision sustainable infrastructure rating system. Harvard University Graduate School of Design and the Institute for Sustainable Infrastructure," 2015, https://www.sustainableinfrastructure.org. 


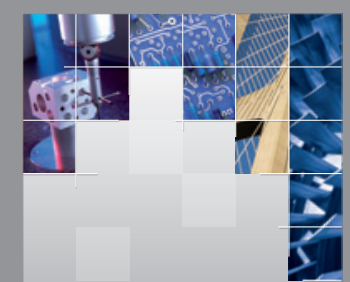

\section{Enfincering}
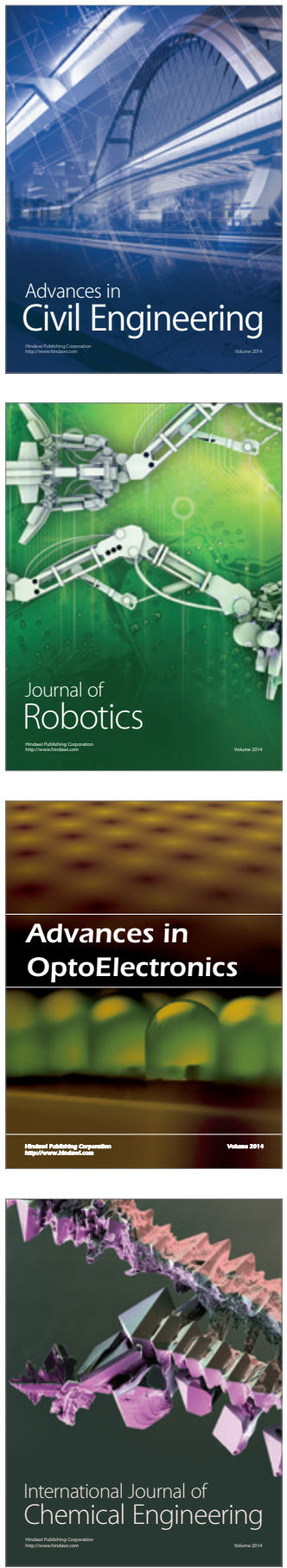

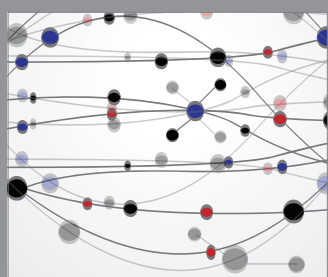

The Scientific World Journal

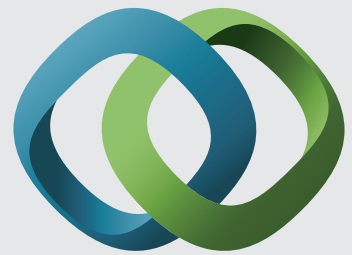

\section{Hindawi}

Submit your manuscripts at

http://www.hindawi.com
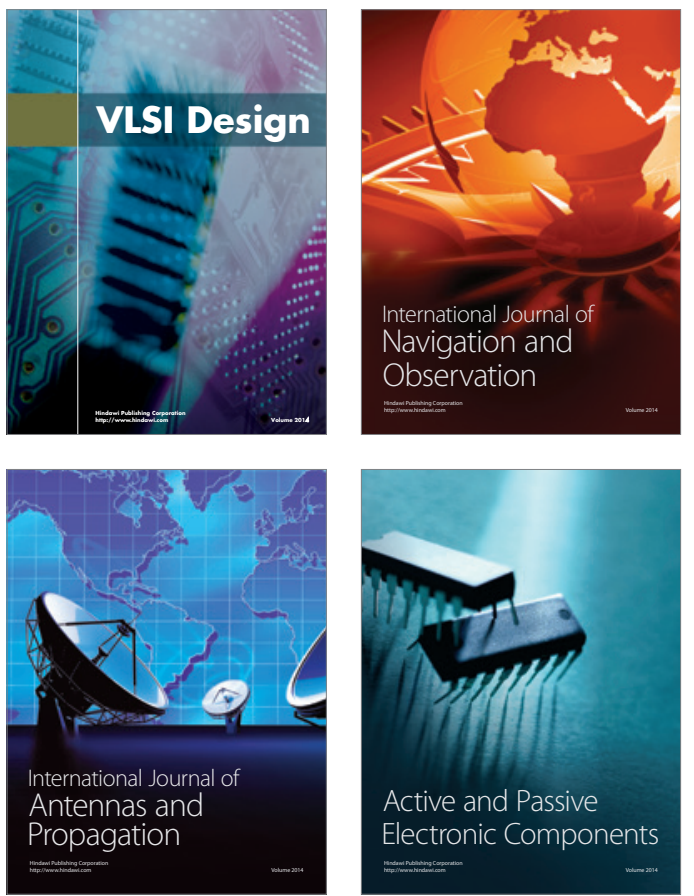
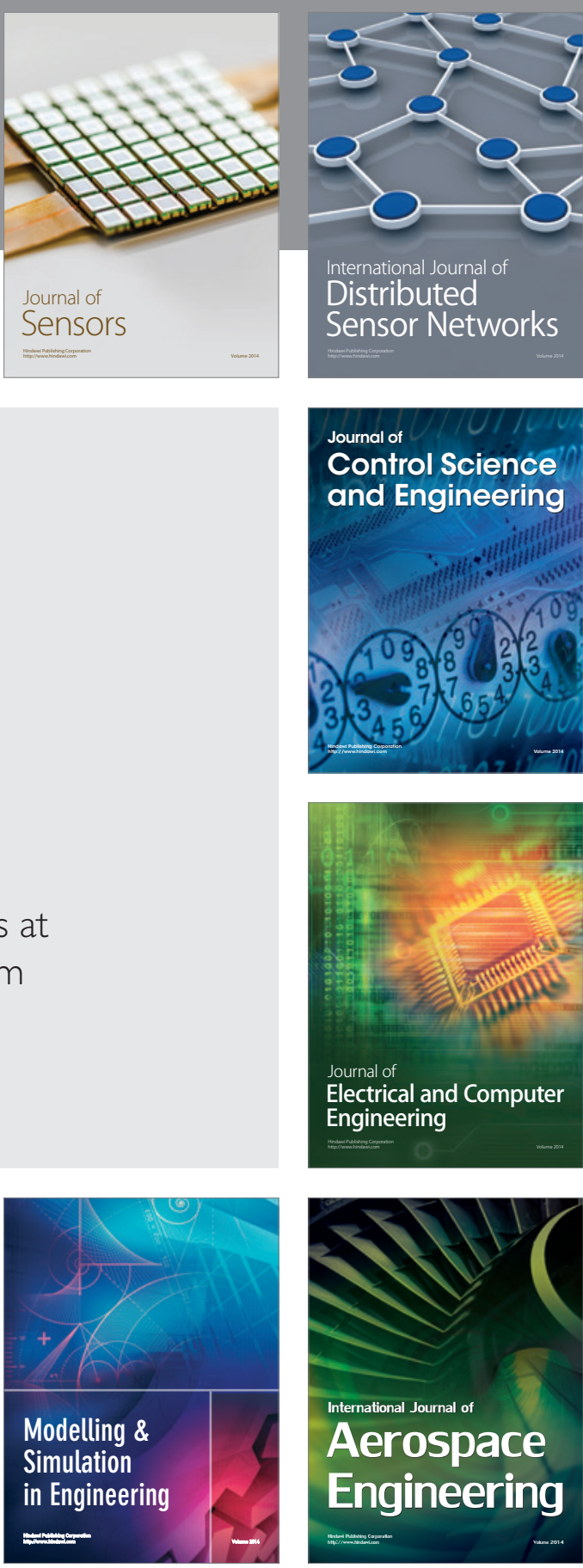

International Journal of

Distributed

Sensor Networks

Journal of

Control Science

and Engineering
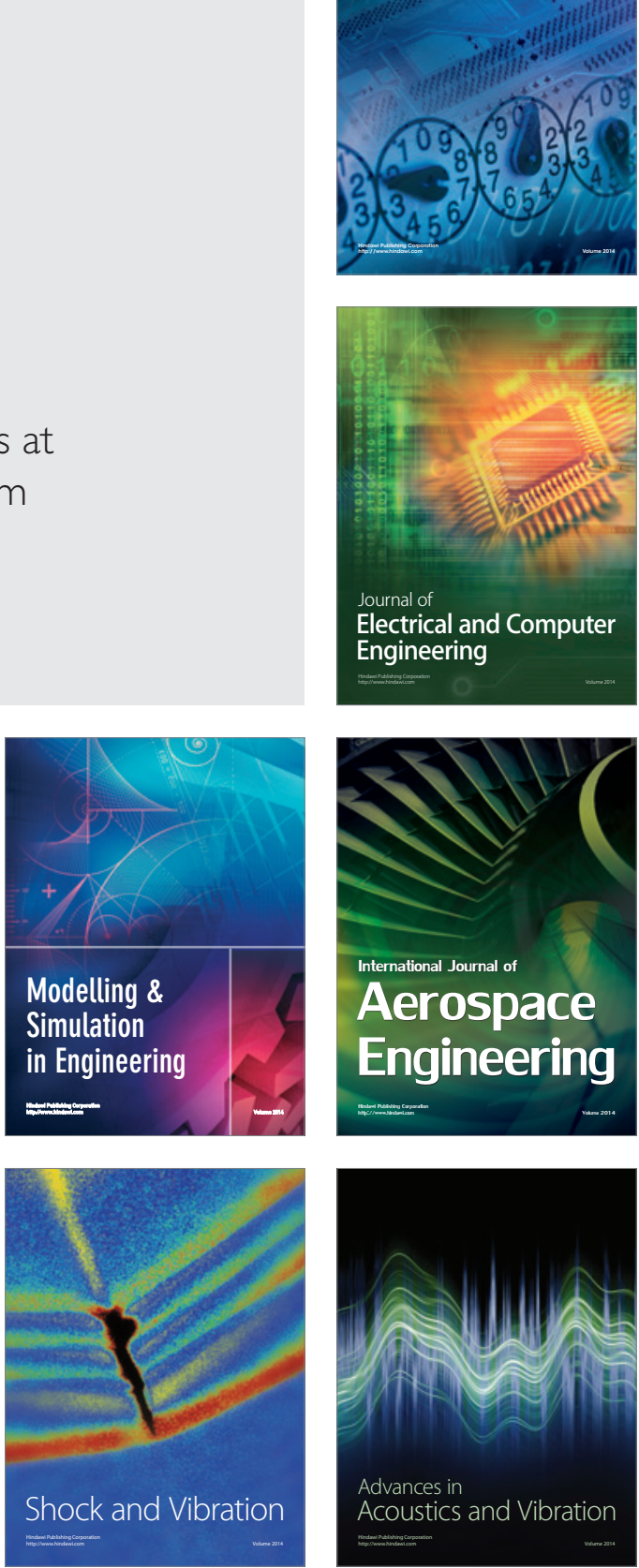